\title{
ENHANCING THE GROWTH AND PRODUCTION OF BLACK CUMIN (NIGELLA SATIVA L.) BY APPLICATION OF HUMIC ACID AND BIOFERTILIZERS
}

\author{
Ragia M. Mazrou \\ Horticulture Department, Faculty of Agriculture, Menoufia University, Shibin El-Kom \\ Received: Jul. 25, 2019 \\ Accepted: Sep. 3, 2019
}

\begin{abstract}
The safe production (chemical-free) of medicinal and aromatic plants has been the focus of interest of various researchers worldwide. Therefore, the aim of this experiment was to study the effect of humic acid (HA) and some bio-fertilizers on growth, seed yield and oil content of black cumin (Nigella sativa L.). Plants were foliar sprayed with $H A$ at 100, 200 and $400 \mathrm{mg} / \mathrm{L}$ while control plants were sprayed with tap water. The bio-fertilizers used in this study were nitrogen fixing bacteria (Bio 1) that consists of Azotobacter chroococcum + Azospirillum brasilense, phosphate solubilizing bacteria (Bio 2) which consists of Bacillus megatherium var. phosphaticum + Bacillus polymyxa and the mixture of (Bio $1+$ Bio 2) as a combination treatment. Plants were not received any bio-fertilizers were set as a control. The growth characters (plant height, branch number and fresh and dry weight per plant), seed yield components (capsule number, seed yield per plant and fed.) were significantly enhanced due to HA and/or biofertilizers treatments relative to the control. In all investigated parameters, the combined treatment of two biofertilizers (Bio 1 + Bio 2) was superior to solely application. Applying HA at 400 $\mathrm{mg} / \mathrm{L}$ had no impact on growth and yield compared with $200 \mathrm{mg} / \mathrm{L}$. The highest seed yield was recorded by the combined treatment of HA at $200 \mathrm{mg} / \mathrm{L}$ and the mixture of Bio $1+$ Bio 2. The volatile oil percentage and yield were also improved by applying $H A$ and/or biofertilizers treatments and the same trend was observed for fixed oil as well. Moreover, the GC-MS analysis of volatile oil indicated that the main constituents were also affected by $\mathrm{HA}$ and/or biofertilizers applications. Generally, the combination between HA and the mixture of biofertilizers increased the percentages of the main components compared to untreated plants. Furthermore, the $N, P, K$, total chlorophyll and carbohydrates were significantly increased due to $\mathrm{HA}$ and/or biofertilizer treatments relative to the control. To reduce the use of chemical fertilizers, minimize the production cost, improve soil structure, increase the quality of black cumin seeds and oils, the combined treatment of $\mathrm{HA}$ at $200 \mathrm{mg} / \mathrm{L}$ and the mixture of Bio 1 + Bio2 was recommended.
\end{abstract}

Key words: Biofertilizers; Humic acid; Volatile oil; Fixed oil; Chlorophyll; Carbohydrates

\section{INTRODUCTION}

Black cumin (Nigella sativa L.), belongs to Ranunculaceae family, is mainly cultivated for the production of seeds and volatile as well as fixed oils. The black cumin oil has several uses for pharmaceutical and food industries (Ustun et al., 1990). The seeds are used for producing the seed cake, a byproduct, obtained by cold pressing for using in the bio-oil production (Sen and
Kar, 2012). Black cumin seeds have several activities such as anthelmintic, insecticidal, antibacterial, antifungal, antimalarial and antitumor. Additionally, the seeds are reported to have diuretic, antispasmodia, carminative, antiseptic and digestive properties (Ali et al., 2008).

Increasing the production of medicinal plants worldwide became an ultimate goal to avoid the side effects chemical 
therapy on human health (Hassan et al., 2012). One of the main factors that affect the production of medicinal plants is fertilization. Several constraints have been raised due to chemical fertilizers applications such as deterioration of soil fertility, increasing the production cost and adverse effects on the environment and public health (Boraste et al., 2009). Reducing pollution practices is very critical factor in sustainable agriculture and using bio-stimulants compounds is an important way to lessen soil pollution (Fawzy et al., 2012).

Recently, several reports focused on humic acid (HA) in various fields such as fertility, soil chemistry, environmental sciences and plant physiology due to the multiple roles that HA can effectively enhance the plant growth and nutrient uptake (Paksoy et al., 2010). HA is a principal constituent of humic substances that are the main organic component of soil (Sani, 2014). It has been found that HA considerably increased the soil organic matter which enhance the plant growth and production (Mahmoud and Hafez, 2010). HA contains many elements that improve the soil fertility and enhance the availability of nutrient elements by holding them on mineral surfaces and, therefore, improve plant growth and yield (Abdel-Razzak, and El-Sharkawy, 2013). HA is complex substance derived from organic matter decomposition and has a relevant role in the cycling of many elements in the environment and in soil (Senesi et al., 1996). Foliar applications of HA promote the growth and increase the yield and quality in several species through increasing nutrient uptake, serving as a source of mineral nutrients and regulating the nutrient release (Karakurt et al., 2009; Bakry et al., 2015). Furthermore, HA influence the amount of sugars, respiration process, nitrate accumulation and amino acids (Boehme et al., 2005).
Bio-fertilizer compounds increase the population of soil microorganisms, especially in the surface layer of root rhizosphere, which create substances that stimulate plant growth (Awad, 2002). The positive effects of rhizobacteria on growth are not only due to nitrogen fixed in the rhizosphere, but also related to synthesize antibiotics and growthpromoting substances including phytohormones. Also, some rhizobacteria has an ability to solubilize phosphates (Hassan et al., 2012; Ali and Hassan, 2014). Several investigators reported the positive effect of biophosphatic fertilization such as Hellal et al. (2011) on dill and Ali and Hassan (2014) on black cumin. The mixed treatment of nitrogen fixing bacteria and phosphate solublizing bacteria resulted in the maximum increase in most of the growth and yield parameters of several medicinal and aromatic plants (Helal et al. 2011; Akhani et al. 2012; Sokhangoy et al. 2012; Hassan et al. 2012; Kahil et al., 2017).

Although HA and biofertilizers are reported to enhance the plant production, little is known about the interactive effects of both of them on growth and secondary metabolites accumulation in medicinal plants. Indeed, few investigations have been conducted so far to assess the interaction between HA and biofertilizers on black cumin plants. Therefore, the aim of this experiment was to study the effect of HA, some biofertilizers and their interactions on the growth, seed yield and oil content of black cumin.

\section{MATERIALS AND METHODS}

\section{Plant materials}

This study was carried out at Faculty of Agriculture, Menoufia University, Shibin El-Kom $\left(30^{\circ} 33^{\prime 2} 24.8^{\prime \prime N}\right.$ $31^{\circ} 00^{\prime} 51.3^{\prime \prime E}$ ) during 2016/ 2017 and 2017/2018 seasons. After preparing the experimental soil, it was divided to $1.8 \mathrm{X}$ 
$1.8 \mathrm{~m}$ plots that contained three rows and each row had 6 hills (22222 plants/fed). The seeds were sown on October $1^{\text {st }}$ in both seasons. The plants were thinned out after four weeks to remain one plant per hill. The physical properties of used soil were $(14.29 \%$ sand, 40.13 silt, 45.58 clay). The chemical properties of soil were $(\mathrm{pH}, 7.98, \mathrm{OM}, 0.17 \%, \mathrm{EC}, 1.30$ $\mathrm{dsm}^{-1}, \mathrm{SO}_{4}^{-2}, 44.49\left(\mathrm{meqL}^{-1}\right), \mathrm{Na}^{+}, 2.17$ $\left(\mathrm{meqL}^{-1}\right), \mathrm{Ca}^{+2}, 42.11\left(\mathrm{meqL}^{-1}\right), \mathrm{HCO}_{3}, 2.03$ (meqL $\left.{ }^{-1}\right), \mathrm{Cl}^{-}, 0.48\left(\mathrm{meqL}^{-1}\right)$, total $\mathrm{N}^{+}, \mathrm{PO}_{4}^{-3}$, $\mathrm{K}^{+}$were $0.18, \quad 0.032$ and $0.036 \%$, respectively). When required, the other cultural practices needed during the growth were done.

\section{Humic acid (HA) treatment}

Potassium humate $(85 \%$ humate and $15 \%$ potassium) was used as a source of $\mathrm{HA}$, which dissolved in tap water to prepare the levels of 100, 200 and 400 $\mathrm{mg} / \mathrm{L}$. The plants were foliar sprayed with HA for three times. The first one was after two months from planting and the treatment was repeated twice at monthly intervals. Control plants were sprayed with tap water.

\section{Biofertilizers treatment}

The biofertilizers used in this study were: nitrogen fixing bacteria (Bio 1) containing [ Azotobacter chroococcum $\left(2.2 \times 10^{9}\right.$ cell $\left./ \mathrm{cm}^{3}\right)+$ Azospirillum brasilense $\left(1.7 \times 10^{9} \quad\right.$ cell $\left.\left./ \mathrm{cm}^{3}\right)\right]$ and phosphate solubilizing bacteria (Bio 2) containing [Bacillus megatherium var. phosphaticum $\left(4.2 \times 10^{9} \mathrm{cell} / \mathrm{cm}^{3}\right)+$ Bacillus polymyxa $\left.\left(3.7 \times 10^{9} \mathrm{cell} / \mathrm{cm}^{3}\right)\right]$ and the mixture between them as a combination treatment (Bio $1+$ Bio 2). Control plants were not treated with any biofertilizers. The seeds wer inoculated with the biofertilizer suspentios for $\mathbf{3 0}$ minutes before planting. Additionally, the soil was also inoculated with biofertilizers at side root zones after 6, 9, and 12 weeks from planting (Ali and Hassan, 2014) and immediately irrigated.
The HA and biofertilizers treatments were arranged in a split plot design in a randomized complete block design with three replicates. The HA treatments were randomly distributed in the main plot while the sub-plots were occupied with biofertilizer treatments.

\section{Growth and seed yield characters}

At harvesting stage (on April $28^{\text {th }}$, 2017 and May $10^{\text {th }}, 2018$ ), random samples of ten plants were collected from each plot for determining the following characters i.e. plant height (cm), number of main branches/plant, plant fresh and dry weight ( $g / p l a n t)$, capsule number/plant, seed yield/plant (g) and seed yield/fed (Kg).

\section{Percentage of volatile and fixed oils determination}

Seed volatile oil was extracted using hydro distillation method as described by British Pharmacopoeia (1963) by the following equation:

Volatile oil percentage $=$ oil volume in the graduated tube/weight of sample x $\mathbf{1 0 0}$.

Samples of $50 \mathrm{~g}$ were milled (just before distillation) and were put directly in extraction units. The percentage of volatile oil was assessed and the oil yield (plant and fed.) was calculated. Anhydrous sodium sulfate was used for volatile oil drying then the oil was stored in dark and cool conditions till GC-MS analysis.

However, fixed oil was estimated by Soxhlet apparatus using petroleum ether (BP $40-60^{\circ} \mathrm{C}$ ) as solvent according to the Association of Official Agricultural Chemists (A.O.A.C. 1980).

\section{GC-MS analysis of volatile}

Samples of volatile oil from the second season were performed using a Hewlett-Packard 5890 A series 11 instrument equipped with flame 
ionization detector (FID) and a carbon wax fused silica column $(50 \mathrm{~m} \times 0.25 \mathrm{~mm}$. i. d., film thickness $0.32 \mu \mathrm{m})$. Helium was used as the carrier gas with a flow rate of $3 \mathrm{~mL} / \mathrm{min}$. Initial oven temperature $40^{\circ} \mathrm{C}$ was held for $2 \mathrm{~min}$, then programmed to rise from 40 to $190{ }^{\circ} \mathrm{C}$ at rate of $4{ }^{\circ} \mathrm{C} / \mathrm{min}$ and the run time was $35.60 \mathrm{~min}$. Volatile oil sample of $1 \mu \mathrm{L}$ (spilt ratio 1:30) was injected manually. Peak area percentages were calculated with a Hewlett-Packard 3396 integrator. The components of volatile oil were identified by comparing the mass spectrum and retention times with those of standards, NIST library of the GC-MS system and literature data.

\section{Nutrient elements investigation}

Black cumin herb samples were oven dried at $70{ }^{\circ} \mathrm{C}$ for 48 hours. Then, samples were milled to obtain suitable material for nutrient analysis. Samples $(0.5 \mathrm{~g})$ were digested in sulphuric and perchloric acids method (Piper, 1967; Jackson, 1978) for mineral content analysis. The micro-Kjeldhl method was used for Nitrogen determination according to Black et al. (1965), phosphorus were colorimetrically assessed using the stannous chloride phosphomolibdic-sulforic acid system and measured at $660 \mathrm{~nm}$ as described by Jackson (1978), while flame photometer was used for potassium measurement (Jackson, 1978).

\section{Chlorophyll determination}

The chlorophyll content in the leaves was assessed according to Metzner et al. (1965) method. The total chlorophyll was recorded as $\mathrm{mg} / \mathrm{g}$ fresh weight.

\section{Total carbohydrates assessment}

Total carbohydrate percentages were determined in leaves. Samples were dried in an electric oven at $70^{\circ} \mathrm{C}$ for 24 hours according to A.O.A.C. (1980). Then, the fine powder was used to determine total carbohydrate percentages according to Herbert et al. (1971).

\section{Statistical analysis}

The obtained results of each season were subjected to the analysis of variance (ANOVA) using SPSS 13.3 program. Statistical differences were investigated using LSDs at $P \leq 0.05$ probability level (Snedecor and Cochran, 1980)

\section{RESULTS AND DISCUSSION}

\section{Vegetative growth characters}

It is very clear from data in Table (1) that the plant height, number of branches/plant and fresh as well as dry weights were considerably increased due to applying different HA levels compared to the control in both seasons. The increment in the abovementioned growth characters were gradual till $200 \mathrm{mg} / \mathrm{L}$ however, the highest level $(400 \mathrm{mg} / \mathrm{L})$ did not cause any significant increase relative to $200 \mathrm{mg} / \mathrm{L}$ level. Applying biofertilizers treatments i.e. nitrogen fixing bacteria (Bio 1) or phosphate solubilizing bacteria (Bio 2) also significantly the growth attributes of black cumin compared to untreated plants. Otherwise, there were no significant differences between Bio 1 and Bio 2 in this respect however; the mixture of both treatments (Bio1 + Bio 2) resulted in the highest values of growth characters. The combined treatment between HA and biofertilizers was very effective in improving the growth of black cumin and the highest values of growth attributes were obtained by the combined of $\mathrm{HA}$ at $200 \mathrm{mg} / \mathrm{L}$ and Bio1 + Bio 2 treatment in both seasons.

Improving the growth of black cumin due to HA application may be ascribed to the role of HA in improving soil physical and chemical characteristics which increase the nutrient mineral adsorption (Bakry et al., 2015). Additionally, potassium humate has beneficial effects on nutrient uptake and also for the transport and the availability of micronutrients required for optimal growth and development (Karakurt et al., 2009). 
Moreover, HA has found to be effective in increasing IAA which stimulates cell division and/or the cell elongation that reflected in improving the plant growth (Abdel Mawgaud et al., 2007; Bakry et al., 2015). Furthermore, HA led to improve the growth of root system which leads to increase the shoot system (Garcia, et al., 2008). Similar trend has been reported by Mohammadipour et al. (2012) and Sani (2014).

The promotion effect of biofertilizers on plant growth could be explained through the role of non-symbiotic $\mathrm{N}_{2}$ Fixing bacteria and phosphate solubilizing in the synthesis of phytohormones, $\mathrm{N}_{2}$ fixation, reduction of membrane potential of the root, synthesis of some enzymes (such as ACC deaminase) that modulate the level of plant hormones as well as the solubilization of inorganic phosphate and mineralization of organic phosphate, which make phosphorus available to the plants (Rodriguez and Fraga, 1999). Moreover, biofertilizers have a great tendency to produce substances such as Gibberellins, Indole acetic acid (IAA), vitamin B complex and these growth hormones have a great potential to increase the plant growth and development (Yasin et al. 2012). Such promotion effects of biofertilizers on medicinal and aromatic plants have been reported (Hellal et al. 2011; Hassan and Ali, 2013; Kahil et al., 2017).

Table 1. Effect of humic acid, biofertilizers and their combination on vegetative growth characters of black cumin during 2016/2017 and 2017/2018 seasons

\begin{tabular}{|c|c|c|c|c|c|c|c|c|c|}
\hline \multicolumn{2}{|c|}{ Treatments } & \multirow{2}{*}{$\begin{array}{c}\text { Plant } \\
\text { height } \\
\text { (cm) }\end{array}$} & \multirow{2}{*}{$\begin{array}{c}\text { Branch } \\
\text { number } \\
\text { /plant }\end{array}$} & \multirow{2}{*}{$\begin{array}{c}\text { Fresh } \\
\text { weight } \\
\text { (g/plant) }\end{array}$} & \multirow{2}{*}{$\begin{array}{c}\text { Dry } \\
\text { weight } \\
\text { (g/plant) }\end{array}$} & \multirow{2}{*}{$\begin{array}{l}\text { Plant } \\
\text { height } \\
(\mathrm{cm})\end{array}$} & \multirow{2}{*}{$\begin{array}{c}\text { Branch } \\
\text { number } \\
\text { /plant }\end{array}$} & \multirow{2}{*}{$\begin{array}{c}\text { Fresh } \\
\text { weight } \\
\text { (g/plant) }\end{array}$} & \multirow{2}{*}{$\begin{array}{c}\text { Dry } \\
\text { weight } \\
\text { (g/plant) }\end{array}$} \\
\hline $\begin{array}{c}\text { Humic } \\
\text { acid (HA) }\end{array}$ & $\begin{array}{c}\text { Biofertilizers } \\
\text { (B) }\end{array}$ & & & & & & & & \\
\hline & & \multicolumn{4}{|c|}{$2016 / 2017$ season } & \multicolumn{4}{|c|}{$2017 / 2018$ season } \\
\hline \multirow{4}{*}{ Control } & Control & 34.75 & 7.56 & 57.98 & 18.72 & 33.88 & 7.48 & 56.82 & 18.35 \\
\hline & Bio $1^{*}$ & 39.52 & 9.22 & 60.78 & 19.01 & 38.57 & 8.98 & 59.56 & 18.62 \\
\hline & Bio $2^{*}$ & 37.81 & 9.11 & 61.31 & 19.32 & 37.67 & 9.02 & 60.08 & 18.93 \\
\hline & Bio 1+Bio 2 & 43.67 & 10.76 & 63.23 & 19.91 & 42.75 & 10.66 & 61.96 & 19.51 \\
\hline \multirow{4}{*}{$100 \mathrm{mg} / \mathrm{L}$} & Control & 36.45 & 8.78 & 59.51 & 18.77 & 36.33 & 8.72 & 58.31 & 18.39 \\
\hline & Bio $1^{*}$ & 42.18 & 10.33 & 62.81 & 19.08 & 42.41 & 10.13 & 61.55 & 18.70 \\
\hline & Bio $2^{*}$ & 41.82 & 10.52 & 63.24 & 20.04 & 41.57 & 10.33 & 61.98 & 19.64 \\
\hline & Bio 1 + Bio 2 & 47.94 & 11.75 & 66.83 & 20.84 & 47.68 & 11.76 & 65.49 & 20.42 \\
\hline \multirow{4}{*}{$200 \mathrm{mg} / \mathrm{L}$} & Control & 38.76 & 9.66 & 63.26 & 19.68 & 37.72 & 9.25 & 61.99 & 19.29 \\
\hline & Bio $1^{*}$ & 46.55 & 11.47 & 67.82 & 21.33 & 46.12 & 11.22 & 66.46 & 20.90 \\
\hline & Bio $2^{*}$ & 45.67 & 11.36 & 68.84 & 22.11 & 45.48 & 11.41 & 67.46 & 21.67 \\
\hline & Bio 1 + Bio 2 & 52.13 & 12.88 & 73.89 & 23.04 & 52.11 & 12.78 & 72.41 & 22.58 \\
\hline \multirow{4}{*}{$400 \mathrm{mg} / \mathrm{L}$} & Control & 39.42 & 9.14 & 62.01 & 19.84 & 38.89 & 9.05 & 61.95 & 20.42 \\
\hline & Bio $1^{*}$ & 46.75 & 11.22 & 67.85 & 21.92 & 46.33 & 10.98 & 67.77 & 21.48 \\
\hline & Bio $2^{*}$ & 46.33 & 11.34 & 68.62 & 22.08 & 46.64 & 11.14 & 68.54 & 22.26 \\
\hline & Bio 1 + Bio 2 & 51.64 & 12.36 & 72.67 & 22.72 & 51.22 & 12.22 & 72.55 & 22.35 \\
\hline \multirow[t]{3}{*}{ LSD 0} & $0.05 \mathrm{HA}$ & 1.87 & 0.69 & 2.34 & 1.67 & 1.85 & 0.66 & 2.29 & 1.62 \\
\hline & B & 1.79 & 0.61 & 2.11 & 1.07 & 1.76 & 0.59 & 1.99 & 1.03 \\
\hline & HAX B & 2.36 & 0.84 & 2.88 & 1.89 & 2.34 & 0.81 & 2.69 & 1.82 \\
\hline
\end{tabular}

Bio 1 means nitrogen fixing bacteria (mixture of Azotobacter chroococcum and Azospirillum brasilense), Bio 2 means phosphate solubilizing bacteria (mixture of Bacillus megatherium var. phosphaticum and Bacillus polymyxa). 


\section{Seed yield components}

The individual application of HA or Biofertilizers significantly enhanced the seed yield components of black cumin compared to the untreated plants. The capsule number/ plant and seed yield (per plant or fed.) were increased with increasing HA level till $200 \mathrm{mg} / \mathrm{L}$ while increasing the dose thereafter did not add any impact in both seasons of study (Table 2). The biofertilizer treatments also increased the seed yield whether they were separately applied or in combination relative to the control. The mixture of Bio 1+ Bio 2 recorded higher seed yield relative to the solely application in both experimental seasons. The interaction between $\mathrm{HA}$ and biofertilizers recorded the highest seed yield of black cumin and the best treatment was HA at $200 \mathrm{mg} / \mathrm{L}$ and Bio1 + Bio 2 treatment in both seasons. By applying this treatment the seed yield/fed was increased by 93.67 and $92.87 \%$ over than the control in the first and second seasons, respectively. These results could be explained through the effective role of HA in improving the growth of black cumin which reflected in increasing the seed yield. El-Sharkawy and AbdelRazzak (2010) found that HA contains plant hormone-like material (cytokinins) which possibly led to keep nutrient balance that in turn enhances the growth and yield. In accordance with these results, several reports proved the yield increase due to HA (Abdel-Razzak and EISharkawy, 2013; Bakry et al., 2015). Biofertilizers also improved the seed yield attributes and this improvement is a logic result because of the positive effects of HA in the growth. Similar results have been documented (Akhani et al., 2012; Hassan et al., 2012; Ali and Hassan, 2014).

\section{3. volatile and fixed oil content in the seeds \\ Data presented in Table (3) indicate} that the volatile oil percentage and yield (per plant and fed) were progressively and significantly enhanced by HA application compared to the untreated plants in both experimental seasons. The treatment of $200 \mathrm{mg} / \mathrm{L}$ recorded the highest volatile oil yield and a slight decrease was observed thereafter when $400 \mathrm{mg} / \mathrm{L}$ was applied. The separate application of nitrogen fixing bacteria (Bio 1) or phosphate solubilizing bacteria (Bio 2) considerably increase the volatile oil yield compared to the control in both seasons of study. Otherwise, the combined biofertilizers treatment (Bio1 + Bio 2) was superior to the solely application. The impact of HA and biofertilizers on volatile oil yield was clearly observed by the interaction treatments since the oil yield was maximized. The treatment of $\mathrm{HA}$ at 200 $\mathrm{mg} / \mathrm{L}$ and Bio1 + Bio 2 recorded the highest volatile oil yield in the two experimental seasons. The volatile oil yield/fed was increased by 203.13 and $212.26 \%$ relative to the untreated plants in 2016/2017 and 2017/2018 seasons, respectively. The same trend was observed concerning the fixed oil content of black cumin seeds and the results go in the same direction of volatile oil (Table 4). HA and biofertilizers increased the fixed oil content wheather applied as a separate or interaction treatment, however the interaction had a higher impact in both seasons. The fixed oil yield was maximized when the treatment of $\mathrm{HA}$ at $200 \mathrm{mg} / \mathrm{L}$ and Bio1 + Bio 2 was applied in the two experimental seasons. The current results are in agreement of Noroozisharaf and Kaviani (2018) on Thymus vulgaris and Aiyafar et al. (2015) Nigella sativa who reported that HA improved the volatile oil content. Moreover, increasing the fixed oil due to 
HA application has been documented (Bakry et al., 2015). The promotion effect of biofertilizers on volatile oil content has been previously documented (Hassan and Ali, 2013; Ali and Hassan, 2015). Biofertilizers application increased the uptake of phosphorus which is a main constituent of phospholipids, phosphoproteins, nucleic acids and coenzymes. Adenosine triphosphate (ATP) is the most important compound in which phosphate group one linked by pyrophosphate bonds. The energy absorbed during photosynthesis or released during respiration is utilized in the synthesis of the pyrophosphate bounds in ATP. In this form, the energy can be conveyed to various undergoing processes such as activation uptake and the synthesis of various organic compounds such as volatile oil (EIGhadban et al., 2003).

Table 2. Effect of humic acid, biofertilizers and their combination on seed yield components of black cumin during 2016/2017 and 2017/2018 seasons

\begin{tabular}{|c|c|c|c|c|c|c|c|}
\hline \multicolumn{2}{|c|}{ Treatments } & \multirow{2}{*}{$\begin{array}{c}\text { Capsule } \\
\text { number/p } \\
\text { lant }\end{array}$} & \multirow{2}{*}{$\begin{array}{c}\text { Seed } \\
\text { yield } \\
\text { (g/plant) }\end{array}$} & \multirow{2}{*}{$\begin{array}{c}\text { Seed } \\
\text { yield } \\
(\mathbf{k g} / \mathrm{fed})\end{array}$} & \multirow{2}{*}{$\begin{array}{l}\text { Capsule } \\
\text { number/ } \\
\text { plant }\end{array}$} & \multirow{2}{*}{$\begin{array}{c}\text { Seed } \\
\text { yield } \\
\text { (g/plant) }\end{array}$} & \multirow{2}{*}{$\begin{array}{c}\text { Seed } \\
\text { yield } \\
(\mathbf{k g} / \mathrm{fed}\end{array}$} \\
\hline $\begin{array}{l}\text { Humic } \\
\text { acid (HA) }\end{array}$ & $\begin{array}{c}\text { Biofertilizers } \\
\text { (B) }\end{array}$ & & & & & & \\
\hline & & \multicolumn{3}{|c|}{$2016 / 2017$ season } & \multicolumn{3}{|c|}{$2017 / 2018$ season } \\
\hline \multirow{4}{*}{ Control } & Control & 14.48 & 7.58 & 168.44 & 13.87 & 7.43 & 165.11 \\
\hline & Bio $1^{*}$ & 16.66 & 8.12 & 180.44 & 16.23 & 8.08 & 179.55 \\
\hline & Bio $2^{*}$ & 17.92 & 8.08 & 179.55 & 18.79 & 8.04 & 178.66 \\
\hline & Bio 1+ Bio 2 & 19.37 & 8.79 & 195.33 & 19.11 & 8.67 & 192.66 \\
\hline \multirow{4}{*}{$100 \mathrm{mg} / \mathrm{L}$} & Control & 16.87 & 8.92 & 198.22 & 16.69 & 8.85 & 196.66 \\
\hline & Bio $1^{*}$ & 19.65 & 9.16 & 203.55 & 19.34 & 9.05 & 201.11 \\
\hline & Bio $2^{*}$ & 19.72 & 9.48 & 210.66 & 19.66 & 9.33 & 207.33 \\
\hline & Bio 1+ Bio 2 & 23.33 & 9.96 & 221.33 & 22.98 & 9.75 & 216.66 \\
\hline \multirow{4}{*}{$200 \mathrm{mg} / \mathrm{L}$} & Control & 19.88 & 9.80 & 217.78 & 19.91 & 9.66 & 214.66 \\
\hline & Bio $1^{*}$ & 22.18 & 11.12 & 247.11 & 22.19 & 10.98 & 244.00 \\
\hline & Bio $2^{*}$ & 22.36 & 12.96 & 288.00 & 22.41 & 12.72 & 282.66 \\
\hline & Bio 1+ Bio 2 & 27.59 & 14.68 & 326.22 & 27.49 & 14.33 & 318.44 \\
\hline \multirow{4}{*}{$400 \mathrm{mg} / \mathrm{L}$} & Control & 18.96 & 9.37 & 208.22 & 18.25 & 9.54 & 212.00 \\
\hline & Bio $1^{*}$ & 21.38 & 10.98 & 244.00 & 21.48 & 10.76 & 239.11 \\
\hline & Bio $2^{*}$ & 21.86 & 12.81 & 284.66 & 21.77 & 12.66 & 281.33 \\
\hline & Bio 1+ Bio 2 & 26.75 & 14.62 & 324.89 & 26.38 & 14.11 & 313.55 \\
\hline \multicolumn{2}{|c|}{ LSD 0.05 HA } & 1.64 & 0.39 & 9.73 & 1.62 & 0.37 & 9.68 \\
\hline \multirow{2}{*}{\multicolumn{2}{|c|}{$\begin{array}{c}B \\
\text { HAX B }\end{array}$}} & 1.48 & 0.32 & 8.84 & 1.45 & 0.30 & 8.76 \\
\hline & & 1.92 & 0.51 & 10.91 & 1.95 & 0.49 & 10.02 \\
\hline
\end{tabular}

Bio 1 means nitrogen fixing bacteria (mixture of Azotobacter chroococcum and Azospirillum brasilense), Bio 2 means phosphate solubilizing bacteria (mixture of Bacillus megatherium var. phosphaticum and Bacillus polymyxa). 
Table 3. Effect of humic acid, biofertilizers and their combination on volatile oil content of black cumin during 2016/2017 and 2017/2018 seasons

\begin{tabular}{|c|c|c|c|c|c|c|c|}
\hline \multicolumn{2}{|c|}{ Treatments } & \multirow{2}{*}{$\begin{array}{c}\text { Volatile } \\
\text { oil (\%) }\end{array}$} & \multirow{2}{*}{$\begin{array}{l}\text { Volatile oil } \\
\text { yield } \\
\text { (mL/plant) }\end{array}$} & \multirow{2}{*}{$\begin{array}{c}\text { Volatile } \\
\text { oil yield } \\
\text { (L/fed) }\end{array}$} & \multirow{2}{*}{$\begin{array}{c}\text { Volatile } \\
\text { oil (\%) }\end{array}$} & \multirow{2}{*}{$\begin{array}{c}\text { Volatile oil } \\
\text { yield } \\
\text { (mL/plant) }\end{array}$} & \multirow{2}{*}{$\begin{array}{c}\text { Volatile } \\
\text { oil yielc } \\
\text { (L/fed) }\end{array}$} \\
\hline $\begin{array}{l}\text { Humic } \\
\text { acid (HA) }\end{array}$ & $\begin{array}{c}\text { Biofertilizers } \\
\text { (B) }\end{array}$ & & & & & & \\
\hline & & \multicolumn{3}{|c|}{$2016 / 2017$ season } & \multicolumn{3}{|c|}{$2017 / 2018$ season } \\
\hline \multirow{4}{*}{ Control } & Control & 0.23 & 0.017 & 0.387 & 0.21 & 0.016 & 0.347 \\
\hline & Bio $1^{*}$ & 0.27 & 0.022 & 0.487 & 0.26 & 0.021 & 0.467 \\
\hline & Bio $2^{*}$ & 0.28 & 0.023 & 0.503 & 0.27 & 0.022 & 0.482 \\
\hline & Bio 1 + Bio 2 & 0.30 & 0.026 & 0.586 & 0.29 & 0.025 & 0.559 \\
\hline \multirow{4}{*}{$100 \mathrm{mg} / \mathrm{L}$} & Control & 0.24 & 0.021 & 0.476 & 0.23 & 0.020 & 0.452 \\
\hline & Bio $1^{*}$ & 0.29 & 0.027 & 0.590 & 0.28 & 0.025 & 0.563 \\
\hline & Bio $2^{*}$ & 0.30 & 0.028 & 0.632 & 0.29 & 0.027 & 0.601 \\
\hline & Bio 1 + Bio 2 & 0.32 & 0.032 & 0.708 & 0.31 & 0.030 & 0.672 \\
\hline \multirow{4}{*}{$200 \mathrm{mg} / \mathrm{L}$} & Control & 0.26 & 0.025 & 0.566 & 0.24 & 0.023 & 0.515 \\
\hline & Bio $1^{*}$ & 0.31 & 0.034 & 0.766 & 0.29 & 0.032 & 0.708 \\
\hline & Bio $2^{*}$ & 0.33 & 0.043 & 0.950 & 0.32 & 0.041 & 0.905 \\
\hline & Bio 1 + Bio 2 & 0.36 & 0.053 & 1.174 & 0.34 & 0.049 & 1.083 \\
\hline \multirow{4}{*}{$400 \mathrm{mg} / \mathrm{L}$} & Control & 0.26 & 0.024 & 0.541 & 0.25 & 0.024 & 0.530 \\
\hline & Bio $1^{*}$ & 0.30 & 0.033 & 0.732 & 0.29 & 0.031 & 0.693 \\
\hline & Bio $2^{*}$ & 0.32 & 0.041 & 0.911 & 0.30 & 0.038 & 0.844 \\
\hline & Bio 1 + Bio 2 & 0.35 & 0.051 & 1.137 & 0.33 & 0.047 & 1.035 \\
\hline \multicolumn{2}{|c|}{ LSD 0.05 HA } & 0.02 & 0.01 & 0.13 & 0.02 & 0.01 & 0.11 \\
\hline \multicolumn{2}{|r|}{ B } & 0.01 & 0.004 & 0.09 & 0.01 & 0.005 & 0.08 \\
\hline \multicolumn{2}{|c|}{ HA X B } & 0.05 & 0.02 & 0.24 & 0.04 & 0.02 & 0.21 \\
\hline
\end{tabular}

Bio 1 means nitrogen fixing bacteria (mixture of Azotobacter chroococcum and Azospirillum brasilense), Bio 2 means phosphate solubilizing bacteria (mixture of Bacillus megatherium var. phosphaticum and Bacillus polymyxa). 
Table 4. Effect of humic acid, biofertilizers and their combination on fixed oil content of black cumin during 2016/2017 and 2017/2018 seasons

\begin{tabular}{|c|c|c|c|c|c|c|c|}
\hline \multicolumn{2}{|c|}{ Treatments } & \multirow[b]{2}{*}{$\begin{array}{c}\text { Fixed oil } \\
(\%)\end{array}$} & \multirow[b]{2}{*}{$\begin{array}{l}\text { Fixed oil } \\
\text { yield } \\
\text { (mL/plant) }\end{array}$} & \multirow[b]{2}{*}{$\begin{array}{c}\text { Fixed oil } \\
\text { yield } \\
\text { (L/fed) }\end{array}$} & \multirow[b]{2}{*}{$\begin{array}{c}\text { Fixed oil } \\
\text { (\%) }\end{array}$} & \multirow[b]{2}{*}{$\begin{array}{l}\text { Fixed oil } \\
\text { yield } \\
\text { (mL/plant) }\end{array}$} & \multirow[b]{2}{*}{$\begin{array}{c}\text { Fixed oil } \\
\text { yield } \\
\text { (L/fed) }\end{array}$} \\
\hline $\begin{array}{l}\text { Humic } \\
\text { acid (HA) }\end{array}$ & $\begin{array}{c}\text { Biofertilizers } \\
\text { (B) }\end{array}$ & & & & & & \\
\hline & & \multicolumn{3}{|c|}{$2016 / 2017$ season } & \multicolumn{3}{|c|}{$2017 / 2018$ season } \\
\hline \multirow{4}{*}{ Control } & Control & 24.57 & 1.86 & 41.39 & 23.88 & 1.77 & 39.43 \\
\hline & Bio $1^{*}$ & 25.67 & 2.08 & 46.32 & 24.95 & 2.02 & 44.80 \\
\hline & Bio $2^{*}$ & 25.54 & 2.06 & 45.86 & 24.86 & 2.00 & 44.42 \\
\hline & Bio 1 + Bio 2 & 25.89 & 2.28 & 50.57 & 25.73 & 2.23 & 49.57 \\
\hline \multirow{4}{*}{$100 \mathrm{mg} / \mathrm{L}$} & Control & 25.11 & 2.24 & 49.77 & 24.92 & 2.21 & 49.01 \\
\hline & Bio $1^{*}$ & 26.87 & 2.46 & 54.69 & 26.77 & 2.42 & 53.84 \\
\hline & Bio $2^{*}$ & 26.92 & 2.55 & 56.71 & 26.81 & 2.50 & 55.59 \\
\hline & Bio 1 + Bio 2 & 27.13 & 2.70 & 60.05 & 27.04 & 2.64 & 58.59 \\
\hline \multirow{4}{*}{$200 \mathrm{mg} / \mathrm{L}$} & Control & 26.15 & 2.56 & 56.95 & 26.05 & 2.52 & 55.92 \\
\hline & Bio $1^{*}$ & 27.81 & 3.09 & 68.72 & 27.77 & 3.05 & 67.76 \\
\hline & Bio $2^{*}$ & 27.93 & 3.62 & 80.44 & 27.86 & 3.54 & 78.75 \\
\hline & Bio $1+$ Bio 2 & 28.12 & 4.13 & 91.73 & 28.07 & 4.02 & 89.39 \\
\hline \multirow{4}{*}{$400 \mathrm{mg} / \mathrm{L}$} & Control & 25.93 & 2.43 & 53.99 & 25.79 & 2.46 & 54.67 \\
\hline & Bio $1^{*}$ & 27.78 & 3.05 & 67.78 & 27.66 & 2.98 & 66.14 \\
\hline & Bio $2^{*}$ & 27.83 & 3.57 & 79.22 & 27.78 & 3.52 & 78.15 \\
\hline & Bio $1+$ Bio 2 & 28.08 & 4.11 & 91.23 & 28.02 & 3.95 & 87.86 \\
\hline \multicolumn{2}{|c|}{ LSD 0.05 HA } & 0.82 & 0.112 & 5.44 & 0.81 & 0.13 & 5.38 \\
\hline \multicolumn{2}{|c|}{ B } & 0.65 & 0.083 & 4.58 & 0.64 & 0.07 & 4.39 \\
\hline \multicolumn{2}{|c|}{ HAXB } & 1.03 & 0.159 & 6.67 & 1.01 & 0.24 & 6.56 \\
\hline
\end{tabular}

Bio 1 means nitrogen fixing bacteria (mixture of Azotobacter chroococcum and Azospirillum brasilense), Bio 2 means phosphate solubilizing bacteria (mixture of Bacillus megatherium var. phosphaticum and Bacillus polymyxa).

\section{Volatile oil constituents}

Eleven components were detected and defined by GC-MS analysis of black cumin seed volatile oil. These components were a -pinene, P-Cymene, Y-terpinene, limonene, caryophylene, borneol, thymoquinone, trans-anethol, carvone, thymol and eugenol (Table 5). The main volatile oil components were 
thymoquinone, trans-anethol and carvone. Interestingly, HA and/or biofertilizers treatments positively affect the volatile oil components. In general, the highest values of volatile oil components were observed when the treatment of $\mathrm{HA}$ at $200 \mathrm{mg} / \mathrm{L}$ and Bio1 + Bio 2 was applied. These results supported the previous findings of Aiyafar et al. (2015) on Nigella sativa and
Noroozisharaf and Kaviani (2018) on Thymus vulgaris who found that HA had a great effect on improving the volatile oil constituents and increased the main components detected in volatile oil. Improving the volatile oil constituents due to biofertilizers treatment has been reported (Hellal et al., 2011; Hassan et al., 2012; Ali and Hassan, 2014).

Table 5. Effect of humic acid, biofertilizers and their combination on the main components of black cumin volatile oil

\begin{tabular}{|c|c|c|c|c|c|c|c|c|c|c|c|c|}
\hline \multicolumn{2}{|c|}{ Treatments } & \multirow{2}{*}{ 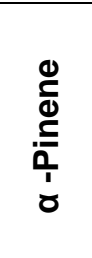 } & \multirow{2}{*}{ 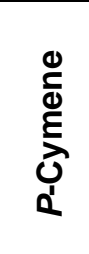 } & \multirow{2}{*}{\begin{tabular}{l}
$\frac{0}{d}$ \\
$\frac{1}{d}$ \\
\hdashline$\frac{2}{2}$ \\
$\frac{1}{1}$ \\
$>$
\end{tabular}} & \multirow{2}{*}{$\begin{array}{l}\underset{\Xi}{\Phi} \\
\stackrel{\Xi}{\Xi} \\
\stackrel{\Xi}{\Xi}\end{array}$} & \multirow{2}{*}{ 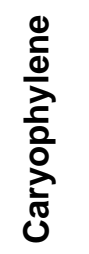 } & \multirow{2}{*}{ 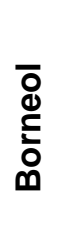 } & \multirow{2}{*}{ 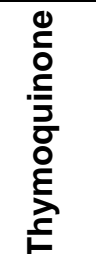 } & \multirow{2}{*}{ 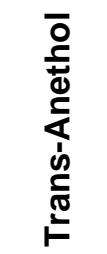 } & \multirow{2}{*}{ 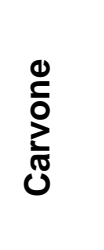 } & \multirow[b]{2}{*}{ 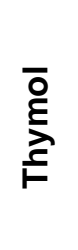 } & \multirow{2}{*}{ 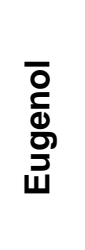 } \\
\hline $\begin{array}{l}\text { Humic } \\
\text { acid } \\
\text { (HA) }\end{array}$ & $\begin{array}{c}\text { Biofertilizers } \\
\text { (B) }\end{array}$ & & & & & & & & & & & \\
\hline \multirow{4}{*}{ Control } & C & 1.22 & 6.45 & 4.14 & 6.21 & 2.16 & 6.47 & 20.40 & 11.35 & 9.98 & 2.97 & 5.33 \\
\hline & Bio $1^{*}$ & 1.25 & 6.51 & 4.19 & 6.37 & 2.21 & 6.56 & 20.88 & 11.58 & 10.14 & 3.10 & 5.51 \\
\hline & Bio $2^{*}$ & 1.24 & 6.55 & 4.18 & 6.34 & 2.23 & 6.59 & 21.2 & 11.54 & 10.32 & 3.14 & 5.59 \\
\hline & Bio 1+ Bio 2 & 1.27 & 8.12 & 4.49 & 6.65 & 2.35 & 6.63 & 21.92 & 11.98 & 10.66 & 3.22 & 5.68 \\
\hline \multirow{4}{*}{$\begin{array}{c}100 \\
\mathrm{mg} / \mathrm{L}\end{array}$} & Control & 1.13 & 6.67 & 4.01 & 6.51 & 2.15 & 6.46 & 21.44 & 11.43 & 10.11 & 3.14 & 5.38 \\
\hline & Bio $1^{*}$ & 1.15 & 7.55 & 4.40 & 6.80 & 2.25 & 6.77 & 23.37 & 12.40 & 10.29 & 3.25 & 5.54 \\
\hline & Bio $2^{*}$ & 1.12 & 7.68 & 4.48 & 7.03 & 2.23 & 6.96 & 23.90 & 12.39 & 10.62 & 3.34 & 5.58 \\
\hline & Bio 1+ Bio 2 & 1.18 & 7.89 & 4.64 & 7.54 & 2.46 & 7.04 & 25.11 & 12.78 & 10.75 & 3.56 & 5.85 \\
\hline \multirow{4}{*}{$\begin{array}{c}200 \\
\mathrm{mg} / \mathrm{L}\end{array}$} & Control & 1.20 & 6.71 & 4.12 & 6.50 & 2.18 & 6.63 & 21.61 & 12.24 & 10.61 & 3.28 & 5.41 \\
\hline & Bio $1^{*}$ & 1.22 & 8.24 & 4.94 & 6.82 & 2.46 & 6.89 & 24.67 & 12.88 & 10.98 & 3.39 & 5.72 \\
\hline & Bio $2^{*}$ & 1.21 & 8.21 & 5.19 & 6.96 & 2.47 & 7.27 & 25.16 & 12.73 & 11.40 & 3.42 & 5.73 \\
\hline & Bio 1+ Bio 2 & 1.28 & 8.89 & 5.38 & 8.25 & 2.71 & 7.54 & 26.55 & 13.14 & 11.63 & 3.67 & 5.91 \\
\hline \multirow{4}{*}{$\begin{array}{c}400 \\
\mathrm{mg} / \mathrm{L}\end{array}$} & Control & 1.21 & 6.70 & 4.25 & 7.61 & 2.30 & 6.82 & 21.9 & 12.23 & 10.74 & 3.54 & 5.48 \\
\hline & Bio $1^{*}$ & 1.15 & 8.22 & 4.74 & 8.12 & 2.66 & 7.47 & 25.05 & 12.79 & 11.72 & 3.77 & 5.63 \\
\hline & Bio $2^{*}$ & 1.21 & 8.21 & 5.24 & 8.25 & 2.64 & 7.89 & 26.87 & 12.68 & 11.85 & 3.75 & 5.68 \\
\hline & Bio 1+ Bio 2 & 1.29 & 8.81 & 6.11 & 10.41 & 3.25 & 9.10 & 29.65 & 12.89 & 12.15 & 4.19 & 5.94 \\
\hline
\end{tabular}

Bio 1 means nitrogen fixing bacteria (mixture of Azotobacter chroococcum and Azospirillum brasilense), Bio 2 means phosphate solubilizing bacteria (mixture of Bacillus megatherium var. phosphaticum and Bacillus polymyxa). 
5. Chemical analysis ( $N, P, K$, chlorophyll and carbohydrates)

It is obvious from data in Table (6) that $\mathrm{N}, \mathrm{P}$ and $\mathrm{K}$ percentages, total chlorophyll content and total carbohydrates in the herb increased due to HA application. The increment was gradual with increasing HA level till $200 \mathrm{mg} / \mathrm{L}$ and decreased thereafter in both seasons. In the same direction, biofertilizer treatments improved the abovementioned chemical analysis in the herb compared with the control. Using the mixture of biofertilizers (Bio 1+Bio 2) was more effective than individual application in this respect. The highest values of chemical analysis were observed when the interaction between HA and biofertilizers was applied in both experimental seasons. The highest values in this concern were obtained by the treatment of $\mathrm{HA}$ at $200 \mathrm{mg} / \mathrm{L}$ and Bio1 + Bio 2. This treatment maximized N, P and $K$ percentages, total chlorophyll content and total carbohydrates in the herb in both seasons.

Increasing the nutrient content due to HA treatment are previously reported (Aiyafar et al., 2015; Noroozisharaf and Kaviani, 2018). HA is considered to motivate microbial activity which increased the enhancement of soluble $P$ and total $N$ content (Busato et al., 2012). Otherwise, HA plays a role in the nitrate uptake through interacting with plasma membrane. Additionally, it can enhance the solubility of soil $\mathbf{P}$ compounds with its chelating capacity (Pinton et al., 1999). It has been found that enzymes related to assimilation pathways (nitrate reductase, glutamate dehydrogenase and glutamine synthetase) were incited by HA application (Hernandez et al. 2015). The positive effects of HA on chlorophyll content and total carbohydrates could be ascribed to an increased in $\mathrm{CO}_{2}$ assimilation and photosynthetic rate which increased mineral uptake by the plant (Ameri and Tehranifar, 2012) and HA may probably cause an increase in the chlorophyll synthesis (Bakry et al., 2015). Increasing the photosynthetic efficiency due to HA treatment led to enhance biosynthesis of carbohydrates which are utilized in plant growth (Bakry et al., 2015). Similar positive effects of HA on chlorophyll and carbohydrates have been reported (Mohammadipour et al., 2012; Abdel-Razzak and El-Sharkawy, 2013).

Increasing the microorganisms in the soil due to biofertilizers also produce growth promoting substances resulting in more efficient absorption of nutrients and consequently $N, P$ and $K$ percentages were increased (Ali and Hassan, 2014). In this regard, Rodriguez and Fraga (1999) found that the nonsymbiotic $\mathrm{N}_{2}$-fixing bacteria produced adequate amounts of IAA and cytokinins with increasing the surface area per unit root length and enhanced the root hair branching with an eventual increase on the uptake of nutrients from the soil. Additionally, improving the total chlorophyll and carbohydrates due to biofertilizers may be due to the role of cytokinins, which secreted by $\mathbf{N}_{2}$-fixers, in reducing the chlorophyll loss (Gaballah 1995). In addition, PSB stimulated chlorophyll synthesis through encourages pyridoxal enzymes formation that plays an important role in $\alpha$-amino levulinic acid synthetase as a primary compound in chlorophyll synthesis (Mahfouz and Sharaf-Eldin, 2007). A positive correlation between chlorophyll and carbohydrate has been reported (Hassan and Ali, 2013). Therefore, the synthesis of photosynthetic pigments in leaves may be an induced factor for carbohydrate synthesis and hence the carbohydrate percentage was increased in black cumin herb. 
Table 6. Effect of humic acid, biofertilizers and their combination on nitrogen, phosphorus, potassium, total chlorophyll and total carbohydrates of black cumin during 2016/2017 and 2017/2018 seasons

\begin{tabular}{|c|c|c|c|c|c|c|c|c|c|c|c|}
\hline \multicolumn{2}{|c|}{ Treatments } & \multirow[b]{2}{*}{$\mathbf{N}(\%)$} & \multirow[b]{2}{*}{$\begin{array}{c}\mathbf{P} \\
(\%)\end{array}$} & \multirow{2}{*}{\multicolumn{2}{|c|}{$\begin{array}{l}\text { Total } \\
\text { Chloro- } \\
\text { (\%) } \text { phyll } \\
\text { (mg/g } \\
\text { FW) }\end{array}$}} & \multirow{2}{*}{$\begin{array}{c}\begin{array}{c}\text { Total } \\
\text { carbo- } \\
\text { hydrates } \\
(\%)\end{array}\end{array}$} & \multirow[b]{2}{*}{$\begin{array}{c}\mathbf{N} \\
(\%)\end{array}$} & \multirow[b]{2}{*}{$\mathbf{P}(\%)$} & \multirow[b]{2}{*}{$\mathrm{K}(\%)$} & \multirow{2}{*}{$\begin{array}{c}\text { Total } \\
\text { Chloro- } \\
\text { phyll } \\
\text { (mg/g } \\
\text { FW) }\end{array}$} & \multirow{2}{*}{$\begin{array}{c}\text { Total } \\
\text { carbo- } \\
\text { hydrates } \\
\text { (\%) }\end{array}$} \\
\hline $\begin{array}{c}\text { Humic } \\
\text { acid } \\
\text { (HA) }\end{array}$ & $\begin{array}{l}\text { Biofertilizers } \\
\text { (B) }\end{array}$ & & & & & & & & & & \\
\hline & & & & \multicolumn{3}{|c|}{ 2016/2017 season } & \multicolumn{5}{|c|}{$2017 / 2018$ season } \\
\hline \multirow{4}{*}{ Control } & Control & 1.53 & 0.22 & 1.69 & 0.97 & 11.14 & 1.49 & 0.23 & 1.66 & 0.95 & 11.18 \\
\hline & Bio $1^{*}$ & 1.59 & 0.24 & 1.75 & 1.02 & 11.59 & 1.52 & 0.25 & 1.73 & 0.99 & 11.62 \\
\hline & Bio $2^{*}$ & 1.57 & 0.26 & 1.77 & 1.04 & 11.53 & 1.55 & 0.26 & 1.75 & 1.02 & 11.66 \\
\hline & Bio $1+$ Bio 2 & 1.68 & 0.27 & 1.89 & 1.17 & 12.22 & 1.63 & 0.28 & 1.84 & 1.11 & 12.31 \\
\hline \multirow{4}{*}{$\begin{array}{c}100 \\
\mathrm{mg} / \mathrm{L}\end{array}$} & Control & 1.55 & 0.23 & 1.77 & 1.03 & 11.84 & 1.54 & 0.23 & 1.72 & 0.98 & 11.78 \\
\hline & Bio $1^{*}$ & 1.66 & 0.26 & 1.89 & 1.19 & 12.66 & 1.63 & 0.25 & 1.86 & 1.07 & 12.71 \\
\hline & Bio $2^{*}$ & 1.64 & 0.28 & 1.97 & 1.21 & 12.79 & 1.64 & 0.27 & 1.94 & 1.11 & 12.74 \\
\hline & Bio $1+$ Bio 2 & 1.72 & 0.30 & 2.11 & 1.27 & 13.51 & 1.70 & 0.31 & 2.08 & 1.21 & 13.57 \\
\hline \multirow{4}{*}{$\begin{array}{c}200 \\
\mathrm{mg} / \mathrm{L}\end{array}$} & Control & 1.61 & 0.29 & 1.87 & 1.13 & 12.63 & 1.59 & 0.28 & 1.85 & 1.05 & 12.65 \\
\hline & Bio $1^{*}$ & 1.78 & 0.33 & 2.24 & 1.25 & 14.41 & 1.72 & 0.32 & 2.19 & 1.15 & 14.11 \\
\hline & Bio $2^{*}$ & 1.75 & 0.34 & 2.27 & 1.27 & 14.51 & 1.73 & 0.33 & 2.24 & 1.17 & 14.19 \\
\hline & Bio $1+$ Bio 2 & 1.84 & 0.37 & 2.39 & 1.33 & 15.46 & 1.81 & 0.36 & 2.36 & 1.22 & 15.51 \\
\hline \multirow{4}{*}{$\begin{array}{c}400 \\
\mathrm{mg} / \mathrm{L}\end{array}$} & Control & 1.59 & 0.27 & 1.85 & 1.15 & 12.59 & 1.57 & 0.27 & 1.81 & 1.03 & 12.44 \\
\hline & Bio $1^{*}$ & 1.72 & 0.32 & 2.23 & 1.24 & 14.33 & 1.71 & 0.31 & 1.20 & 1.12 & 14.28 \\
\hline & Bio $2^{*}$ & 1.73 & 0.30 & 2.28 & 1.25 & 14.48 & 1.72 & 0.32 & 2.25 & 1.14 & 14.31 \\
\hline & Bio $1+$ Bio 2 & 1.81 & 0.34 & 2.36 & 1.30 & 15.36 & 1.79 & 0.35 & 2.34 & 1.23 & 15.29 \\
\hline \multirow{3}{*}{$\begin{array}{r}\text { LSD } \\
\qquad\end{array}$} & $0.05 \mathrm{HA}$ & 0.15 & 0.004 & 0.05 & 0.051 & 1.31 & 0.14 & 0.006 & 0.06 & 0.053 & 1.35 \\
\hline & B & 0.09 & 0.003 & 0.04 & 0.032 & 1.07 & 0.07 & 0.004 & 0.05 & 0.034 & 1.09 \\
\hline & HAX B & 0.22 & 0.021 & 0.08 & 0.061 & 1.46 & 0.24 & 0.026 & 0.09 & 0.065 & 1.51 \\
\hline
\end{tabular}

Bio 1 means nitrogen fixing bacteria (mixture of Azotobacter chroococcum and Azospirillum brasilense), Bio 2 means phosphate solubilizing bacteria (mixture of Bacillus megatherium var. phosphaticum and Bacillus polymyxa).

\section{Conclusion}

It could be concluded that applying HA and/or biofertilizers promoted the vegetative growth and increased the seed yield of black cumin. The volatile and fixed oils also improved due to HA and/or biofertilizers application. The volatile oil constituents were also positively affected. To decrease the cost of black cumin production, improve soil structure, reducing environmental hazards, enhance leveraging agriculture and obtain seeds with high quality fixed and volatile oils, the treatment of $\mathrm{HA}$ at 200 $\mathrm{mg} / \mathrm{L}$ combined with the mixture of Bio 1 (NFB) + Bio 2 (PSB) was recommended.

\section{REFERENCES}

A.O.A.C. (1980). Official Methods of Analysis of the Association of Official Agricultural Chemists (A.O.A.C.) $12^{\text {th }}$ Ed. Washington. D.C. 
Abdel-Mawgoud, A. M. R., N. H. M. ElGreudy, Y. I. Helmy and S. M. Singer (2007). Responses of tomato plants to different rates of humic based fertilizer and NPK fertilization. J. Applied Sci. Research. 3(2):169-174.

Abdel-Razzak, H.S. and G.A. El-Sharkawy (2013). Effect of Biofertilizer and Humic Acid Applications on Growth, Yield, Quality and Storability of Two Garlic (Allium sativum L.) Cultivars. Asian Journal of Crop Science, 5: 4864.

Aiyafar, S., H. Poudineh and $M$. Forouzandeh (2015). Effect of Humic Acid on Qualitative and Quantitative Characteristics and Essential Oil of Black Cumin (Nigella sativa L.) under Water Deficit Stress. DAV International Journal of Science 4 (2): 89-102.

Akhani, A., M.T. Darzi and M. H.S. Hadi (2012). Effects of bio-fertilizer and plant density on yield components and seed yield of Coriander (Coriandrum Sativum). International Journal of Agriculture and Crop Sciences. 4-16:1205-1211.

Ali, A., A.A. Alkhawajah, M.A. Randhawa and N.A. Shaikh (2008). Oral and interaperitoneal LD50 of thymoquinone an active principal of Nigella sativa in mice and rats. Journal Ayub medicinal Coll, 20(2): 2527.

Ali, E. and F. Hassan (2014). Bioproduction of Nigella sativa L. seeds and oil in Taif area. Int. J. Curr. Microbiol. App. Sci 3(1): 315-328.

Ameri, A. and A. Tehranifar (2012). Effect of Humic Acid on Nutrient Uptake and Physiological Characteristic Fragaria $x$ Ananassa Var: Camarosa. Journal of Biological Environment Science. 6: 7779.

Awad, E.M. (2002). Effect of compost and some bio-fertilizers on growth, yield and quality of potato crop (Solanum tuberosum L.). J. Agric. Sci. Mansoura Univ., 27: 5525-5537.

Bakry, A. B., M. Sadak and M. F. Elkaramany (2015). Effect of humic acidand sulfur on growth, some biochemical constituents, yield and yield attributes of flax grown under newly reclaimed sandy soils. ARPN Journal of Agricultural and Biological Science. 10 (7): 247-259.

Black, C.A., D.D. Evans and L.E. Ensminger (1965). Methods of soil analysis. Agron. J. Amer. Soc. Agron. Inc. Publ., Madison, Wisconsin, U.S.A.

Boehme, M., J. Schevtschenko and I. Pinker (2005). Iron Supply of Cucumbers in Substrate Culture with Humate. Acta Hort. 697 ISHS. 41(1): 329-335.

Boraste, A., K.K. Vamsi, A. Jhadav, Y. Khairnar, N. Gupta, S. Trivedi, P. Patil, G. Gupta, M. Gupta, A.K. Mujapara and B. Joshi (2009). Biofertilizers: A novel tool for agriculture. International Journal of Microbiology Research, 1(2): 23-31

British Pharmacopea (1963). Determination of volatile oil in drugs. Published by Pharmaceutical Press. London. W.C.I.

Busato, J.G., L.S. Lima, N.O. Aguiar, L.P. Canellas and F.L. Olivares (2012). Changes in labile phosphorus forms during maturation of vermicompost enriched with phosphorus-solubilizing and diazotrophic bacteria. Bioresour Technol 110:390-395.

El-Ghadban, E.A., A.M. Ghallab and A.F. Abdel-Wahab (2003). Effect of organic fertilizer and biofertilization on growth, yield and chemical composition of marjoram plants under newly reclaimed soil conditions. J. Agric. Sci. Mansoura, 28 (9): 69576973.

El-Sharkawy, G.A. and H.S. Abdel-Razzak (2010). Response of cabbage plants (Brassica oleraceae var. capitata L.) to 
fertilization with chicken manure, mineral nitrogen

Fawzy, Z.F., Z.S. El-Shal, L. Yunsheng, O. Zhu and O.M. Sawan (2012). Response of garlic (Allium sativum, L.) plants to foliar spraying of some bio-stimulants under sandy soil condition. J. Appl. Sci. Res., 8: 770-776.

Gaballah, M.A. (1995). Effect of water logging and kinetin on the stability of leaf membranes, leaf osmotic potential, soluble carbon and nitrogen components and chlorophyll content of Ricinus communis plants. Phyton. Horn., 30: 199-208.

Garcia, M. C. V., F. S. Estrellam, M. J. Lopez and J. Moreno (2008). Influence of compost amendment on soil biological properties and plants. Dynamic Soil, Dynamic Plant. 1: 1-9.

Hassan, F.A.S. and E.F. Ali (2013). A comparative study between traditional mineral nutrition and other alternative sources on anise plant. Europe. J. Sci. Res. 106 (2): 201-212.

Hassan, F.A.S., E.F. Ali and S.A. Mahfouz (2012). Comparison between different fertilization sources, irrigation frequency and their combinations on the growth and yield of coriander plant. Australian Journal of Basic and Applied Sciences, 6(3): 600-615.

Hellal, F.A., S.A. Mahfouz and F.A.S. Hassan (2011). Partial substitution of mineral nitrogen fertilizer by biofertilizer on (Anethum graveolens L.) plant. Agri. Biol. J. North America, 2(4): 652-660.

Herbert, D., P.J. Phipps and R.E. Strange (1971). Determination of total carbohydrates. Methods in Microbiology, 5(8): 290-344.

Hernandez, O.L., A. Calderi'n, R. Huelva, D. Martı'nez-Balmori, F. Guridi, N.O. Aguiar, F.L. Olivares and L.P. Canellas (2015). Humic substances from vermicompost enhance urban lettuce production. Agron Sustain Dev 35: 225-232

Jackson, M.L. (1978). Soil Chemical Analysis. Fall Indian Private. Ltd. New Delhi.

Kahil, A. A., F. A. S. Hassan and E. F. Ali (2017). Influence of bio-fertilizers on growth, yield and anthocyanin content of Hibiscus sabdariffa L. plant under Taif region conditions. Annual Research \& Review in Biology. 17 (1): 1-15.

Karakurt, Y., H. Unlu, H. Unlu and H. Padem (2009). The influence of foliar and soil fertilization of humic acid on yield and quality of pepper. Acta Agric. Scand., 59: 233-237.

Mahfouz, S.A. and M.A. Sharaf-Eldin (2007). Effect of mineral vs. biofertilizer on growth, yield, and essential oil content of fennel (Foeniculum vulgare Mill.). Int. Agrophysics, 21: 361-366.

Mahmoud, A.R. and M.M. Hafez (2010). Increasing productivity of potato plants (Solanum tuberosum L.) by using potassium fertilizer and humic acid application. Int. J. Acad. Res., 2: 83-88.

Metzner, H., H. Rau and H. Senger (1965). Unter suchungen zur synchronisier barteit einzelner pigmentan angel mutanten von chlorela. Planta, 65: 186.

Mohammadipour, E., A. Golchin, J. Mohammadi, N. Negahdar and $M$. Zarchini (2012). Effect of humic acid on yield and quality of marigold (Calendula officinalis L.). Annals of Biological Research, 11: 5095-5098.

Noroozisharaf, A. and M. Kaviani (2018). Effect of soil application of humic acid on nutrients uptake, essential oil and chemical compositions of garden thyme (Thymus vulgaris L.) under greenhouse conditions. Physiol Mol Biol Plants 24(3): 423-431. 
Paksoy, M., O. Turkmen and A. Dursun (2010). Effects of potassium and humic acid on emergence, growth and nutrient contents of okra (Abelmoschus esculentus L.) seedling under saline soil Soil conditions. Afr. J. Biotechnol., 9: 5343-5346.

Pinton, R., S. Cesco, G. lacolettig, S. Astolfi and Z. Varanini (1999). Modulation of NO-3 uptake by waterextractable humic substances: involvement of root plasma membrane H? ATPase. Plant Soil 215:155-161

Piper, C.S. (1967). Soil and Plant Analysis. 2nd Ed., Asia Pub. House, Bombay, India.

Rodriguez, H. and R. Fraga (1999). Phosphate solubilizing bacteria and their role in plant growth promotion. Biotech. Adv., 17(4-5): 319-339.

Sani, B. (2014). Foliar application of humic acid on plant height in canola. APCBEE Procedia, 8 :82 - 86.

Sen, N. and Y. Kar (2012). Pyrolysis of black cumin seed cake in a fixed-bed reactor. J. Biomass Bioenergy 35:4297-4304.
Snedecor, G.W. and W.G. Cochran (1980). Statistical Methods $7^{\text {th }}$ Ed., lowa State Univ., Press., Ames. lowa, U.S.

Senesi, N., T.M. Miano and G. Brunetti (1996). Humic-like substances in organic amendments and effects on native soil humic substances. In: Piccolo, A. Ed, Humic Substances in Terrestrial Ecosystems. USA, New York: Elsevier.

Sokhangoy, S.H., K. Ansari and E. Asli (2012). Effect of bio-fertilizers on performance of dill (Anethum graveolens). Iranian Journal of Plant Physiology 2 (4): 547-552.

Ustun, G., L. Kent, N. Cekin and H. Civelekoglu (1990). Investigation of the technological properties of Nigella sativa, L. (black cumin) seed oil. JAOCS, 67 (12): 71-86.

Yasin, M., K. Ahmad, W. Mussarat and A. Tanveer (2012). Bio-fertilizers, substitution of synthetic fertilizers in cereals for leveraging agriculture. Crop Environ., 3: 62-66. 


\title{
تحسين نمو وانتاج نبات حبة البركة باستخدام المعاملة بحمض الهيوميك والأسمدة الحيوية البركه باسنغانة
}

\author{
راجيا متولي مزروع
}

قسم البساتين - كلية الزراعة - جامعة المنوفية

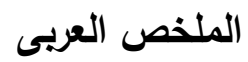
يعتبر الاتتاج الامن للنباتات الطبية وإلعطرية محور اهتمام العديد من الباحثين فى جميع أنحاء العالم ويالتالى كان الهلف من هذه التجرية دراسة تأثير حمض الهيوميك ويعض الأسمدة الحيوية على النموومحصول البذرة ومحصول الزيت وأيضا مكونات الزيت الطيار على نبات حبة البركة. فى هذه التجرية تم رش النباتات بحامض الهيوميك بتركيزات 100 و200 و400 مجم/لتر بينما نباتات الكنترول تم رشها بماء الصنبور. تم استخدام ثلاث معاملات من الأسمدة الحيوية

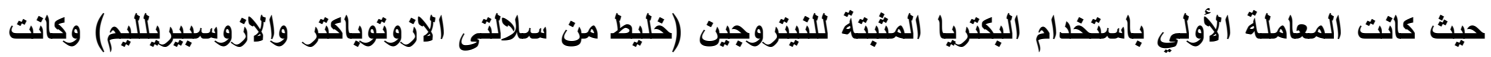

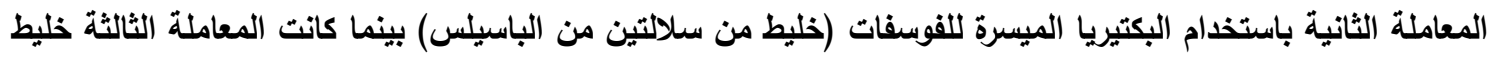

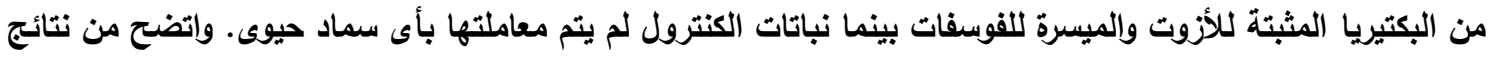
التجرية أن صفات النمو مثل ارتفاع النبات وعد الافرع والوزن الطازج والجاف للنبات وكذلك محصول البذور من حيث عدد

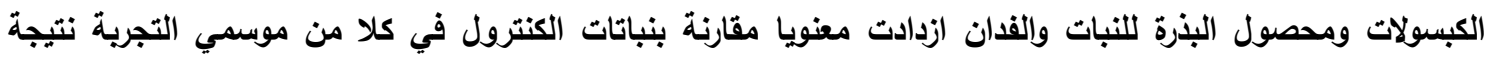

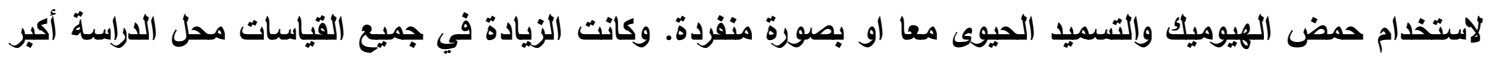

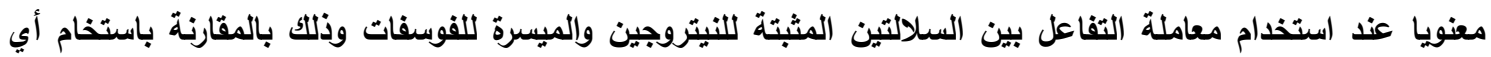

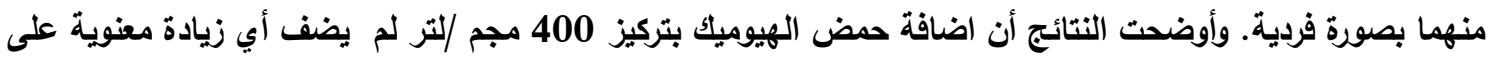
صفات النمو والمحصول مقارنة بتركيز 200 مجم/لتر. وقد سجلت معاملة التفاعل بين كل من حمض الهيوميك 200

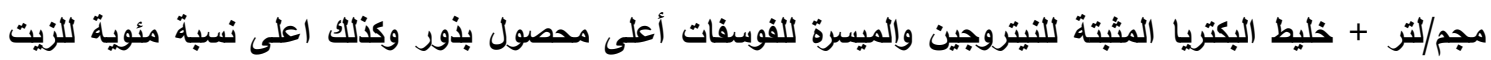

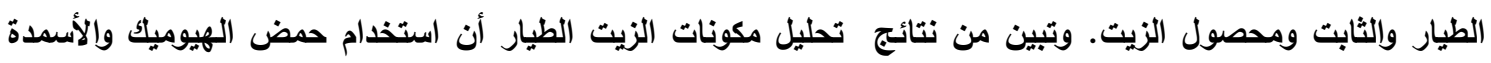

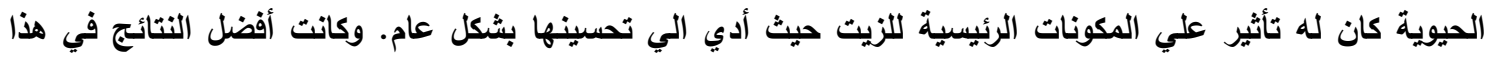

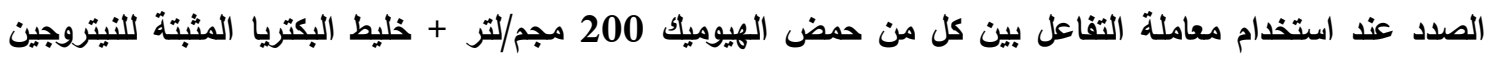
والميسرة للفوسفات. كما أثثارت النتائج المتحصل عليها أن استخدام حمض الهيوميك والأسمدة الحيوية أدى الى زيادة

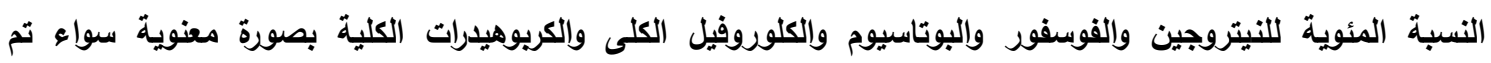
استخدامها بصورة منفردة أو كمعاملة تداخل بينهما مقارنة بالكنترول. وأوصت النتائج بأنه لتقليل استخدام الأسمدة والكية الكيميائية وتقليل التكاليف وتحسين خواص التربة وزيادة جودة ومحصول الزيت فى نبات حبة البركة يمكن استخدام معاملة التفاعل بين حمض الهيوميك 200 مجم/لتر + خليط البكتريا المثبتة للنيتروجين والميسرة للفوسفات كسماد حيوى.

أسماء السادة المحكمين كلية الزراعة - جامعة كفر الثيخ 
Enhancing the growth and production of black cumin (Nigella sativa L.) ............. 